\title{
HUMAN VALUES IN TERE LIYE'S NOVEL BIDADARI-BIDADARI SURGA
}

\author{
Hidayati ${ }^{1}$, Arifuddin ${ }^{2}$, Ratna Sari Dewi ${ }^{3}$ \\ ${ }^{1,2}$ Universitas Harapan Medan \\ ${ }^{3}$ Universitas Muslim Nusantara Al-Washliyah \\ e-mail: yatihida853@gmail.com
}

Received: 2021-11-16

Accepted: 2021-11-21

\begin{abstract}
The research is based on the reality depicted in the novel BidadariBidadari Surga by Tere Liye that the human values of the millennial generation are currently starting to fade. Human value is a basic trait that humans have to love each other and not be concerned with selfinterest. This study aims to provide input to the community, especially millennial generations, that human values must be maintained to obtain a harmonious life. Humanitarian problems arise when a sense of concern and tolerance for others suffers a setback due to the nonfunctioning of the institution optimally. The method used is descriptive qualitative showing the phenomena of human values in society by collecting written data in the forms of words, phrases and sentences containing human values in the novel. The data collection is done by means of note-taking method, referring to the topics of discussion. The results show that human values in the forms of love, sacrifice and tolerance are depicted in the novel Bidadari-Bidadari Surga by Tere Liye. The results of this study are expected to raise awareness among the millennial of the importance of human values for the continuity of peaceful and harmonious life to improve lifestyle quality on an ongoing basis.
\end{abstract}

Kata Kunci : humanity values, love, sacrifice, tolerance

\section{Introduction}

Literary works, especially the fictions, are currently much loved by young people or the millennial. At the present time it is not hard to find and read a novel as everyone could get any literary work, either in physical form or obtained from various applications using gadgets. However, the fact is that there are still many who read novels with the intention of just looking for entertainment without understanding the meaning conveyed by the author. In the novel Bidadari-Bidadari Surga by Tere Liye, there are many written and implied human values to be be used as guidelines for society, especially the millennial. The human values in the novel give inspiration, particularly to the academicians to conduct further researches by linking human values with literature. The linkage is by involving the values of life in society with human values in literary works. In this case, literature is a reflection of society and is seen as a medium to represent life, not only presenting the romance of lovers, but also a life story about human values that can change the perspective and life of the readers. 
Tere Liye in his works talks a lot about human values. Bidadari-Bidadari Surga is a novel that tells about the existence of human values described by the author in a monologue style and easy to understand. Human Values are universal and can be developed to shape human character. These human values consist of truth, virtue, peace, compassion, non-violence, sacrifice, and tolerance. Human values are concerned with human behavior and actions in accordance with norms and respect to human dignity. The values of truth are the same as human values, the qualities of things important or useful in life (Gulliver, 2014).

The novel Bidadari-Bidadari Surga tells about human values, interesting and important to analyze more deeply because it contains educational values that can be imitated to be applied in everyday life. This novel tells the story of a girl named Laisa who works hard to be able to send her four younger siblings, Dalimunte, Ikanuri, Wibisana and Yashinta, despite the fact that Laisa has no blood ties to them. Laisa has to quit school to fight for the education of her younger siblings. Her patience in dealing with the mischievous attitudes of two of his younger siblings is something that deserves appreciation and to be made example of running a happy life.

Based on the descriptions above, the purposes of this study are as follows:

1. Exposing human values; love, sacrifice and tolerance.

2. Providing moral education to readers, especially the millennial about the importance of human values; love, sacrifice, and tolerance to be applied in social life so as to produce a generation of high and noble character.

\section{Literature Review}

Human values generally mean moral, referring to the generally accepted understanding of good or bad regarding actions, attitudes, and obligations. In relation to literary works, a novel contains the application of morals in the attitudes and behavior of the characters in accordance with their views on morals.

Through the stories, attitudes, and behavior of the characters, readers are expected to be able to take lessons from the moral messages conveyed. Moral in literary works can be seen as mandate and message, usually reflecting the author's view of life, his views on the values of truth, and that is what he wants to convey to the reader; in other words, a literary text generally contains human values. There is the word 'human' in the phrase, human values meaning that these values are unique to human beings and not to animals, and human values must be universal which means that they do not depend on race, group, tradition and culture. Therefore, human values are values that must be understood and practiced by all human beings and every student can learn the social aspects and human values by reading some literary text (Balaji, 2014).

Humans are creatures that have sense and character while the human value is the basic nature of humans to love each other without tending to selfishness. This is in line with Al Syaibany in (Hidayat, 2019) stating that by having values, humans will surely share love to each and every creature and by this will get rid of beastly nature. This is a factor that influences human behavior to be adjusted to an environment.

This research is conducted on the focus of human values: love, sacrifice, and tolerance. Sacrifice is a moral awareness based on sincere intentions to do something for the benefit of others or a group of people. Sacrificing attitudes do not have any thought of reward; the result of everything done is not assessed based on the advantages or other material values. (Murray: 2016). The attitude or act of sacrifice is certainly in line with compassion to the others being done with sincerity. The essence of love itself lies in an 
effort to make other people better. Love is a necessity and also the basis of human life. (Buss: 2018). Sacrifice and love will eventually direct someone to have a high taste. Tolerance is basically an attitude of mutual respect or respecting one and another and the attitude is applied to a situation in which there is a difference with the aim of obtaining a whole and harmonious unity. Tolerance bridges differences so that conflicts can be avoided. Tolerance must be applied in all lines of social life (Doorn: 2014). Therefore the three subject matters are interrelated.

\section{Research Method}

The research was conducted using a qualitative descriptive method (Moleong: 2010) which explains a phenomena and the value of a concept in detail and clearly. The data source is obtained from the novel Bidadari-Bidadari Surga by Tere Liye and the data are in the forms of words, phrases, sentences and dialogues found in the novel. To get the meaning of human values in the novel, the researcher carried out several stages, including conducting library studies. Library studies were carried out to obtain information about human values by reading references related to these matters, then recording all data related to discussion points. The above steps used the note-taking method (Sudaryanto: 2015: 207). The references were in the forms of books, journals and theses as well as research reports, followed by analysis procedures after all the data had been collected. All data were analyzed based on the points discussed systematically.

\section{Discussion}

In the novel Bidadari-Bidadari Surga, Tere Liye focuses more on human values and there are several points of human values that can be described in the novel Bidadari-Bidadari Surga including, the values of love, sacrifice, and tolerance, then these values are described clearly by the author, so that the readers can easily find them because the words, phrases, sentences and dialogues between and among the characters in the novel show human values clearly. The use of beautiful diction also adds to the artistic value in this novel so that it adds a deep impression to the reader, so that the readers are able to capture the deeper emotional outbursts of the characters.

\section{Value of Love}

The value of love possessed by humans is one of the heavenly gifts and this then becomes the basic nature. When someone has the value of love, he or she will spread love to others so as to create a peaceful life. This should also be owned by everyone, especially the young generations so that they will be happier in living their lives.

Liye (2008: 19) reveals how Laisa is unwilling to stop Yashinta, who looks so happy with a shining smile when approaching the beaver's nest when Laisa takes Yashinta and her sisters to the forest to see the beaver. However, suddenly Yashinta runs from her hiding place behind the bushes and approaches the beaver's nest. Laisa wants to stop her, but she is unwilling, to ruin the sweet smile on her beloved sister's face. Here it is seen that Laisa truly loves her sister. This is the part that conveys the message that today many of us are always sacrificing the happiness of others for our personal gain.

There is also a part of the novel showing the value of love for others. Ikanuri finally regrets that he then falls down and could not hold back his tears when he thinks of his sister who is lying because her illness is getting worse and he realizes how much Laisa stands as a true sister who has given all her love to her younger siblings even 
though they are a t times very naughty as kids and do not want to listen to the words of their mother and sister. Because Laisa's love for them is so great they have become what they are today; they have succeeded in achieving their goals.

From the description above, it can be seen that the message conveyed is that by giving and spreading love to others, it is not something that is detrimental, but something extraordinary that can change life from bad to something beautiful. This should be imitated by the readers, especially the millennial, who at this time are still many lacking of love for others; by this all forms of conflict can be avoided.

\section{Value of Sacrifice}

Value of sacrifice is an action that is done with a sense of sincerity for the benefit of others. This is something that is worthy and must be owned by every human being along with the value of love they have because finally, sacrifice and love will be in line towards the same point, namely peace and harmony.

Sacrifice is easy to say but hard to do. Sacrifice is synonymous with love, in true love there must be sacrifice, it can be a small or big. We could say that sacrifice is a consequence of love itself. Sacrifice is an action that goes beyond our obligations, an action that is not obligatory on us, an action that no one can demand us to do. However with the willingness and sincerity we want to do things for others. People who make sacrifices think that their small or big sacrifices will be very useful and meaningful to the person who accepts the sacrifice.

For now sacrifice is rarely done by the community, because at this time people only think about themselves, without thinking about others; actually sacrifice is a very noble act because sacrifice can help someone change their life for the better. Sacrifice is an act of sincere and moral awareness or can also be interpreted as a person's willingness to do something that is usually shown to someone who has a purpose or meaning from his action, in the form of help and does not expect a reward from an action or willingness, purely sincere. Sacrifice is submitted sincerely without any strings attached, without any agreement, without any transaction, whenever needed.

Sacrifice knows no end. Sacrifice is a necessary thing in life. Sacrifice demands nothing of us. No one in this world has never made a sacrifice. A mother sacrifices herself even her life while pregnant and giving birth to her child. A father sacrifices his time and energy to earn a living for his family. A child may sacrifice his will for the sake of his parents. There are sacrifices everywhere and at all times.

Laisa has sacrificed her childhood to her teenage years to work to help her mother support and pay for her younger siblings' schools. For that Laisa has to stop schooling for the happiness of her younger siblings to realize their dreams. In this part there is also a dialogue where little Yashinta thinks that a woman does not have to go to school. This view is because she sees that her older sister Laisa does not go to school without knowing the truth that Laisa gives in to her younger siblings so that they could continue to attend school. Since their father dieds, Laisa has decided to stop her schooling to help their mother earn a living (Liye, 2008: 29, 63).

The sacrifice that is even greater from a Laisa is that she is a person who never complains even in the most difficult circumstances. She is always disciplined and works hard to help her mother support and educate her younger siblings even though she is not related to them by blood. She is willing to not marry during her life for the sake of her beloved siblings. An extraordinary sacrifice when someone does things that are very big and meaningful for others without regard to their own interests. This message is 
conveyed by the author to the readers that sacrifices must be made sincerely and will certainly bring a blessing and benefit to others. This is what Laisa has done (Liye, 2008: $27,84)$.

Another of Laisa's sacrifice shown in the novel is when Laisa has to immediately help her sick sister even though it is already night and there is no more public health center open in their remote village in Lahambay Valley. With all her strength she traverses the difficult and rocky paths among the valleys in order to seek help from students who are doing college tasks in their village. She does not care about the weather; it is raining and so cold that makes her shiver. She does not care about the rocks that cause her leg to hurt until the ankle is shifted for his sister's recovery. But her sacrifice is not in vain. Laisa manages to bring a student to her house to help her sick sister (Liye, 2008: 66, 67, 68)

It is conceivable that if everyone has a sense of sacrifice like this, it is certain that every human being will have bonds and feelings of mutual love and protection for each other so as to create a harmonious life. This is very important for the millennial youth to have so that they will have the nature of sharing and being willing to sacrifice for others. When a person has love, he will then be willing to sacrifice selflessly for others. The message can be captured from the monologue presented by the author in this novel as a precious teaching for everyone of us.

\section{Value of Tolerance}

Tolerance is a commendable attitude in which a person can accept every difference; differences are not the basis for conflict. Through the value of tolerance, differences do not lead to forcing something on others. Differences must be respected because every individual is different.

Etymologically, tolerance means patience and restraint. Meanwhile, in terms of terminology, tolerance is an attitude of mutual respect,, expressing opinions, views, beliefs to fellow human beings who are contrary to oneself. Based on the linguistic meaning, tolerance can be interpreted as the ability of each person to be patient and refrain from things that are not in line with them. With an attitude of tolerance, conflicts and cleavages between individuals and among groups will not occur. Many people refer to tolerance as the main key to peace that should be maintained. This is important to note because each community has diverse backgrounds, ranging from beliefs, ethnicities, races, to skin colors.

The implementation of the attitude of tolerance must be based on an attitude of generosity towards others by paying attention to the principles are held by themselves, namely without sacrificing their own principles.

In interpreting tolerance, there are two points of the concept. First, the negative interpretation stating that tolerance is sufficient requiring an attitude of letting and not hurting other people or groups, whether different or the same; while the second is a positive interpretation stating that tolerance is not just like the first, negative interpretation, but there must be help and support for the existence of other people or other groups.

It can be stated, that tolerance is the attitude of a person who is able to let gracefully, appreciate, acknowledge, respect something without holding grudges. Given the importance of the value of tolerance, we have to remind ourselves that tolerance must be applied in everyday life. This effort is made to avoid conflicts that occur due to lack of respect and appreciation for others. What is needed in society is not just looking 
for similarities and agreements that are not easy to reach; what is most important in diverse societies is mutual understanding. The purpose of developing an attitude of tolerance among the community and other social groups is as a vehicle for training to be implemented and developed widely in people's lives.

By respecting human rights to exercise their rights and freedoms, we mean that tolerance has been created, as the essence of tolerance is to respect anything contrary to personal principles. Without tolerance, conflict and cleavage can occur. Tolerance is the basis for creating a peaceful environment. Tolerance is an important concept that everyone should learn, understand and master. The understanding of tolerance must be understood by everyone to build a society that is free from hatred and cleavage. Tolerant people show strength because they can face different opinions and perspectives. Tolerance is very important in living life together.

Laisa is has a high tolerance value. She still accepts and forgives her siblings' mistakes even though their words have hurt her; in fact she has been the one who has been helping her mother to support their family life. Due to her high tolerance, she does not want to get angry with her siblings who have different views from her, although sometimes they use harsh words directed at her. She never expresses her anger openly to her younger siblings. For her everything that is best should belong to the younger siblings. Even if something bad happens, let it be hers (Liye, 2008: 36).

As humans we cannot impose our personal will on the common good even though we feel something is very important. Here, it is told that the flight attendant on the flight where Ikanuri is one of the passengers asks her to turn off her cell phone, but as $s$ receives a message from Mamak Laisa is sick, she does not heed the rules and continues to force her will to contact her mother who is in the village. Of course, the flight attendant persists in not giving permission to Ikanuri until the debate is won by the flight attendant. The message conveyed by the author is that we must prioritize the interests of the people more than our own interests even though we think it is something very important for us because the interests and safety of the people are more important than our personal interests (Liye, 2008: 10).

In the next paragraph, there is a message of tolerance shown to us. Laisa's sisters do not show their tolerance to Laisa by saying that they are different from her. Laisa has a short body with black skin and dreadlocks, while her younger siblings have white skins and straight hair. However, Laisa is not angry at her sister's words. She has a high tolerance for what her sisters say about their differences. She does not mind her sister's intolerance, she responds with tolerance and love (Liye, 2008: 43).

There is a message that we should have tolerance values for the differences that other people have. In fact, it is these differences that make life more complete and meaningful. If the millennial also have a high value of tolerance for one another, divisions and differences among them do not occur so that frequent brawls between teenagers can be avoided so that millennial teenagers can focus more on their education to reach a bright future.

\section{Conclusion}

From the explanation above, it can be concluded that there are human values in the forms of love, sacrifice, and tolerance depicted through the characters in the novel Bidadari-Bidadari Surga by Tere Liye. The three items of human values have close relationships with one another. When a person has the value of love, he will be willing to sacrifice anything for the sake of others so that these two things lead him to tolerate 
all differences in order to lead to better things in the future. This research is expected to provide teaching about human values to the millennial generation to cultivate human values in themselves, so the description of the struggles and attitudes of the main characters in this novel can provide input for the development of literature and of other studies on norms or values of life. This research is also expected to increase appreciation, tolerance for others, and increase a sense of concern for those who are more in need so that the a generation with high moral values and noble character is born; thus a harmonious and peaceful life can be achieved.

\section{References}

Balaji, Seemusuru Prasad, K. (2016). Teaching Human Values through Literature. Journal of English Language and Literature. Vol.3, No. 2. http://joell.in/wpcontent/uploads/2016/03/85-87TEACHING-OF-HUMAN-VALUES-1.pdf.

Buss, David M. (2018). The Evolution of Love in Humans. ResearchGate. https://www.researchgate.net/publication/329539118_Th_e_Evolution_of_Love _in_Humans

Departemen Pendidikan dan Kebudayaan. 1998. Kamus Besar Bahasa Indonesia. Jakarta: Balai Pustaka

Doorn, Marjoka Van. (2014). The Nature of Tolerance and the Social Circumstances in which It Emerges. University of Amsterdam. ResearchGate. https://www.researchgate.net/publication/268509606_The_nature_of_tolerance_ and_the_social_circumstances_in_which_it_emerges

Gulliver, Lemuel XVI. (2014). Understanding Our Human Values. Oslo: Total Health Publishing.

Hidayat, Tatang dkk. (2019). Prinsip Dasar Falsafah Akhlak Omar Mohammad AlToumy Al-Syaibany dan Implikasinya dalam Pendidikan di Indonesia. Jurnal Kajian Peradaban Islam. JKP1s, Pages 10- 17 Vol.2 N0.1,2019 E-ISSN, 26543974.

Liye, Tere. 2008. Bidadari Surga. Amazon: Republika.

Moleong, Lexy J.(2010). Metodologi Penelitian Kualitatif. Bandung: Rosda Karya

Murray, Carrie Ann. (2016). The Value and Power of Sacrifice. New York: State University of New York, Alabny. https://www.sunypress.edu/pdf/63292.pdf

Sudaryanto, (2015). Metode dan Aneka Teknik Analisis Bahasa Pengantar Penelitian Wahana Kebudayaan Secara Linguistis.Yogyakarta: Sanata Dharma University Press. 